\title{
Real-life Outcomes of Tenofovir Disoproxil Fumarate Monotherapy in Nucleos(t)ide Analogue-naive and Nucleos( $t$ ) ide Analogue-experienced Chronic Hepatitis B Patients: A Single-center Experience
}

\author{
Nükleozit-naive ve Nükleozit Deneyimli Kronik Hepatit B'li Hastalarda Tenofovir Disoproksil \\ Fumarate Monoterapisi Gerçek-yașam Sonuçlarl: Tek Merkez Deneyimi
}

\author{
PInar KORKMAZ1 , Figen ÇEVIK ÇAĞLAN², Nevil AYKIN², Hasan NAZ³ , Onur TOKA4 \\ 1Dumlupınar University Faculty of Medicine, Department of Clinical Microbiology and Infectious Diseases, Kütahya, Turkey \\ 2Eskişehir Yunus Emre State Hospital, Clinic of Clinical Microbiology and Infectious Diseases, Eskişehir, Turkey \\ ${ }^{3}$ Kocaeli State Hospital, Clinic of Clinical Microbiology and Infectious Diseases, Kocaeli, Turkey \\ 4Hacettepe University Faculty of Science, Department of Statistics, Ankara, Turkey
}

\begin{abstract}
Objective: The aim of the study was to evaluate the long-term results of treatment efficacy and safety in nucleos(t)ide analogue-naive (NA-naive) and NA-experienced chronic hepatitis B (CHB) patients receiving tenofovir disoproxil fumarate (TDF) therapy.

Materials and Methods: Data of 99 patients treated with the diagnosis of CHB (hepatitis B surface antigen-positive for more than 6 months) with TDF monotherapy between February 2008 and May 2014 were evaluated retrospectively.

Results: In total, 99 patients (median age: 50 years, $68.7 \%$ male, $21.2 \%$ hepatitis B e-antigen-positive) were included in the study. Thirty patients were NA-naive and 69 patients were NA-experienced. No significant difference was determined between NA-naive and NA-experienced patients regarding the rate of achieving complete virological response at the $1^{\text {st }}, 2^{\text {nd }}, 3^{\text {rd }}, 4^{\text {th }}$, and $5^{\text {th }}$ years of the treatment $(p>0.05)$. Additionally, no significant difference was determined between NA-naive and NA-experienced patients regarding achieving a biochemical response rate at the $1^{\text {st }}, 2^{\text {nd }}, 3^{\text {rd }}, 4^{\text {th }}$, and $5^{\text {th }}$ years of the treatment $(p>0.05)$. In our study, resistance at the end of the $5^{\text {th }}$ year was not found. No patient required discontinuation of the treatment due to adverse effects during treatment.

Conclusion: Data analysis indicates that TDF monotherapy provides an efficient viral suppression in NA-naive and NA-experienced patients at the end of the $5^{\text {th }}$ year of the treatment.

Keywords: Tenofovir, nucleos(t)ide analogue-naive, nucleos(t)ide analogue-experienced, complete virological response
\end{abstract}

öz

Amaç: Bu çalışmada tenofovir disoproksil fumarat (TDF) tedavisi alan nükleos(t)ide analoğu (NA)-naive ve NA-deneyimli kronik hepatit B (KHB) hastalarında tedavi etkinliği ve güvenilirliğine ait uzun dönem sonuçlarının değerlendirilmesi amaçlanmıştır.

Gereç ve Yöntemler: Şubat 2008-Mayıs 2014 tarihleri arasında KHB (6 aydan uzun süredir hepatit B yüzey antijeni-pozitif) tanısıyla TDF tedavisi alan 99 hastaya ait kayıtlar retrospektif olarak değerlendirildi. Bulgular: Toplamda 99 hasta (medyan yaş 50, \%68,7 erkek, \%21,2 hepatit B e-antijeni-pozitif) çalışmaya dahil edildi. Otuz hasta NA-naive, 69 hasta NA-deneyimli idi. NA-naive ve NA-deneyimli hastalarda 1., 2., 3., 4., 5. yillarda komplet virolojik yanıt elde etme oranı açısından anlamlı bir fark tespit edilmedi $(p>0,05)$. NA-naive ve NA-deneyimli hastalarda 1., 2., 3., 4., 5. yillarda biyokimyasal yanıt elde etme oranı açısından anlamlı bir fark tespit edilmedi ( $p>0,05)$. Çalışmamızda TDF tedavisi alırken 5. yıl sonu direnç tespit edilmemiştir. Tedavi süresi boyunca hiçbir hastada yan etki dolayısıyla tedavi sonlandırımak zorunda kalınmamıştır. Sonuç: TDF monoterapi tedavisi NA-naive ve NA-deneyimli hastalarda tedavinin 5. yllı sonunda etkin bir viral süpresyon sağlamaktadır. Anahtar Kelimeler: Tenofovir, nükleos(t)ide analoğu-naive, nükleos(t) ide analoğu-deneyimli, komplet virolojik yanıt

Korkmaz P, Cevik Cağlan F, Aykın N, Naz H, Toka O. Real-life Outcomes of Tenofovir Disoproxil Fumarate Monotherapy in Nucleos(t)ide Analogue-Naive and Nucleos(t)ide Analogue-Experienced Chronic Hepatitis B Patients: A Single-center Experience. Viral Hepat J. 2016;22:92-96.

Address for Correspondence: PInar Korkmaz MD, Dumlupinar University Faculty of Medicine, Department of Clinical Microbiology and Infectious Diseases, Kütahya, Turkey Phone: +90 5055502260 E-mail: drpinarkor@gmail.com Received: 28.10.2016 Accepted: 22.11.2016

CCopyright 2016 by Viral Hepatitis Society / Viral Hepatitis Journal published by Galenos Yaynevi. 


\section{Introduction}

Tenofovir disoproxil fumarate (TDF) is a prodrug of nucleotide analogue tenofovir, a potent and selective inhibitor of hepatitis $B$ virus (HBV) DNA polymerase-reverse transcriptase (1). Initially, TDF was used for the treatment of HIV infection and was then approved for the treatment of chronic hepatitis B (CHB) in 2008 (2). TDF is recommended as a first-line treatment in the guidelines $(3,4)$. Long-term TDF therapy was found to be associated with regression in fibrosis and cirrhosis in $\mathrm{CHB}$ patients at the $5^{\text {th }}$ year of treatment (5). With TDF therapy, an efficient viral suppression without developing resistance was achieved at the $7^{\text {th }}$ year of treatment in clinical trials (6).

TDF has been shown to have a good efficacy in nucleos(t)ide analogue-experienced (NA-experienced) patients $(7,8)$. However, there are a limited number of studies about the efficacy of TDF therapy in NA-experienced patients in our country $(9,10,11)$. Since TDF therapy is a frequently preferred treatment for $\mathrm{CHB}$ in Turkey, long-term data-based outcomes are necessary to determine its efficacy in both NA-naive and NA-experienced patients.

This study aimed to evaluate the long-term, data-based outcomes of treatment efficacy and safety in NA-naive and NA-experienced $\mathrm{CHB}$ patients receiving TDF therapy between February 2008 and May 2014.

\section{Materials and Methods}

\section{Patients}

Data of 99 NA-naive or NA-experienced patients, who received TDF therapy with the diagnosis of $\mathrm{CHB}$ [hepatitis $\mathrm{B}$ surface antigen (HBsAg)-positive for more than 6 months] between February 2008 and May 2014, were retrospectively evaluated. Data were obtained from the outpatient clinic files of the patients. The study was approved by the ethics committee of Eskişehir Yunus Emre State Hospital. The treatment was initiated in hepatitis B envelope antigen ( $\mathrm{HBeAg}$ )-positive patients with alanine aminotransferase $(A L T) \geq 2$ upper limit of normal (ULN), HBV DNA $\geq 2$ upper $\mathrm{IU} / \mathrm{mL}$ and in HBeAg-negative patients with ALT $\geq 2$ ULN, HBV DNA $\geq 2$ $\mathrm{UL} \mathrm{IU} / \mathrm{mL}$, and/or concomitant moderate-severe histological injury at liver biopsy (3). TDF $300 \mathrm{mg} /$ day oral therapy was given as monotherapy/combined therapy [lamivudine (LAM) in 9 patients whose therapy had been switched from LAM to TDF during the first 6 months]. The patients with a history of alcohol consumption, hepatitis C virus, hepatitis D virus, HIV coinfection, hepatocellular carcinoma, decompensated cirrhosis, or autoimmune disease were excluded from the study.

\section{Study Design}

Patient records were accessed for physical examination, complete blood count test and biochemical tests (ALT, aspartate aminotransferase, alkaline phosphatase, gama glutamil transferase, albumin, bilirubin and creatinine) that were performed in all of the patients at the beginning of the TDF treatment. The patients were followed up every 3 months. Complete blood count test, biochemical tests, and HBV DNA measurement were performed every 3-6 months. Viral markers ( $\mathrm{HBsAg}$, anti-HBs, HBeAg, and anti-HBe) were monitored at the beginning and every 6-12 months thereafter. The patients were followed up for hepatocellular carcinoma screenings with abdominal ultrasonography and serum alpha-fetoprotein level. Biopsy was performed in patients without contraindication for liver biopsy. Fibrosis and histology activity indexes were scored according to the Ishak and Knodell scoring systems. HBsAg, anti-HBs, $\mathrm{HBeAg}$, anti-HBe, hepatitis B core antibody, antibody to hepatitis D, antibody to hepatitis C, and antibody to HIV were detected using ELISA assay (DiaSorin, Saluggia, Italy). HBV DNA was detected using polymerase chain reaction (PCR) (2007-2009 COBAS TAGMAN RT-PCR with lower detection limit of $6 \mathrm{IU} / \mathrm{mL}, 2010-2011$ Rotorgene Q RT-PCR with lower detection limit of $20 \mathrm{IU} / \mathrm{mL}, 2012-2013$ Qiagen Artus with lower detection limit of $11 \mathrm{JU} / \mathrm{mL}, 2014-$ Rotorgene 6000 RT-PCR with lower detection limit of $3.8 \mathrm{IU} / \mathrm{mL}$ ).

\section{Treatments and Endpoints}

The primary endpoint was defined as an HBV DNA level undetectable by PCR during TDF treatment. Secondary endpoints were ALT normalization, HBeAg seroconversion, safety, and tolerability. Virologic breakthrough was defined as an increase in serum HBV DNA level of $>1$ log10 copies $/ \mathrm{mL}$ above the treatment nadir during treatment. HBeAg seroconversion was defined as loss of $\mathrm{HBeAg}$ and appearance of anti-HBe antibody in $\mathrm{HBeAg}$-positive patients $(3,4)$.

\section{Statistical Analysis}

Data analysis was performed with the SPSS 20.0 program and relevant graphs were created using MS Excel. During analyses, classified knowledge was interpreted using frequency and percentage and continuous data was interpreted using mean, median, and deviations. Statistical significance was investigated with independent and dependent t-tests in parametric conditions. When parametric hypothesis was not provided, statistical significance was investigated with Wilcoxon and Mann-Whitney $U$ tests and interpreted. A p value of less than 0.05 was considered statistically significant.

\section{Results}

Ninety-nine patients were included in the study. Sixty eight (68.7\%) patients were male and 32 (32.3\%) were female. The

\begin{tabular}{|lllll|}
\hline \multicolumn{5}{|l|}{ Table 1. Baseline characteristics of the patients } \\
\hline $\begin{array}{l}\text { Baseline } \\
\text { demographics }\end{array}$ & $\begin{array}{l}\text { Total } \\
(\mathbf{n = 9 9 )}\end{array}$ & $\begin{array}{l}\mathrm{HBeAg} \\
\text { negative } \\
(\mathbf{n = 7 8})\end{array}$ & $\begin{array}{l}\mathrm{HBeAg} \\
\mathbf{p o s i t i v e} \\
(\mathbf{n = 2 1 )}\end{array}$ & $\begin{array}{l}\mathbf{p} \\
\text { value }\end{array}$ \\
\hline Male (\%) & $68(68.7 \%)$ & $54(69.2 \%)$ & $14(66.7 \%)$ & $>0.05$ \\
\hline Age (years, mean) & $49.77 \pm 12.56$ & $52 \pm 11.6$ & $41.43 \pm 12.73$ & $\leq 0.05$ \\
\hline $\begin{array}{l}\text { Follow-up, } \\
\text { months (median) }\end{array}$ & 37 & 38 & 29 & $>0.05$ \\
\hline $\begin{array}{l}\text { Prior ADV } \\
\text { treatment (\%) }\end{array}$ & $41(41.4 \%)$ & $32(41 \%)$ & $9(42.9 \%)$ & $>0.05$ \\
\hline $\begin{array}{l}\text { NA-naive patients } \\
\text { (\%) }\end{array}$ & $30(30.3 \%)$ & $22(28.2 \%)$ & $8(38.1 \%)$ & $>0.05$ \\
\hline Mean ALT (U/L) & $70.59 \pm 103$ & $73.17 \pm 112$ & $61 \pm 58.9$ & $>0.05$ \\
\hline $\begin{array}{l}\text { Mean HBV DNA } \\
\text { (log10 IU/mL) }\end{array}$ & $4 \pm 2.55$ & $3.5 \pm 2.3$ & $5.96 \pm 2.4$ & $<0.05$ \\
\hline Mean Knodell & $9.11 \pm 3.12$ & $9.32 \pm 3$ & $8.47 \pm 3.44$ & $>0.05$ \\
\hline Mean fibrosis & $2.56 \pm 1.28$ & $2 \pm 1.34$ & $2.33 \pm 1$ & $>0.05$ \\
\hline $\begin{array}{l}\text { HBeAg: Hepatitis B envelope antigen, ADV: Adefovir, NA-naive: Nucleos(t)ide } \\
\text { analogue-naive, ALT: Alanine aminotransferase, HBV: Hepatitis B virus }\end{array}$ \\
\hline
\end{tabular}


mean age of the patients was $50 \pm 13$ years. Baseline characteristics of the patients' status as HBeAg-positive and -negative group and totals are given in Table 1. Patients' previous treatments were investigated. They included the use of more than one drug ladefovir (ADV), LAM, entecavir, interferon, pegylated interferon] in 41 patients $(56.2 \%)$, use of LAM in 16 patients $(21.9 \%)$, use of ADV in 8 patients $(10.9 \%)$, use of interferon in 4 patients $(5.5 \%)$ and use of entecavir in 4 patients $(5.5 \%)$.

The rate of complete virologic response (CVR) was determined to be $78.7 \%, 89 \%, 97.9 \%, 95 \%, 96.5 \%, 97.1 \%$, and $92.8 \%$ at the $3^{\text {rd }}$ month, $6^{\text {th }}$ month, and 1 st $, 2^{\text {nd }}, 3^{\text {rdd }}, 4^{\text {th }}, 5^{\text {th }}$ and $6^{\text {th }}$ years of the treatment, respectively. When $\mathrm{HBeAg}$-positive and negative patients were evaluated, CVR at the end of $3^{\text {rd }}$ month and $6^{\text {th }}$ month was statistically significantly higher in $\mathrm{HBeAg-negative} \mathrm{patients,} \mathrm{but}$ no significant difference could be determined between the two groups in all other periods. CVR rates achieved in HBeAg-positive and negative patients by years are given in Figure 1 .

When CVR in NA-naive and NA-experienced patients was evaluated by month/year, CVR at the end of the 3rd month was found to be significantly higher in the NA-experienced group compared to the NA-naive group ( $p<0.05)$. No significant difference was determined between the two groups regarding CVR in all of the other periods ( $p>0.05)$ (Figure 2). ALT normalization rate was determined to be $86.8 \%, 92.5 \%, 94.9 \%, 96.3 \%, 94.7 \%, 97.1 \%$, and $100 \%$ at the $3^{\text {rd }}$ month, $6^{\text {th }}$ month, 1 st $, 2^{\text {nd }}, 3^{\text {rd }}, 4^{\text {th }}$, $5^{\text {th }}$ and $6^{\text {th }}$ years of the treatment, respectively. A total of 2 patients have completed 6 years of the treatment and virologic and biochemical responses have been maintained so far. ALT normalization rates in $\mathrm{HBeAg-positive} \mathrm{and} \mathrm{-negative} \mathrm{patients} \mathrm{by} \mathrm{month/year} \mathrm{are} \mathrm{given} \mathrm{in}$ Figure 3. ALT normalization rates in NA-naive and NA-experienced patients by month/year are given in Figure 4 . When the patients with and without virologic response at $3^{\text {rd }}$ month and $6^{\text {th }}$ month were compared, it was observed that statistically significantly higher virologic response rates were achieved in HBeAg-negative patients, in patients of higher ages, and in patients with lower mean baseline ALT values and lower log HBV DNA values (p.1\% with).

The $\mathrm{HBeAg}$ seroconversion rate was $9.5 \%$. None of the patients developed loss of HBsAg. Virologic breakthrough developed in a total of 7 patients during treatment. We could not evaluate TDF resistance. Also, we could not evaluate drug resistance in any of our NA-experienced patients. Poor drug compliance and discontinuation of the treatment at their own request was determined in these 7 patients. TDF therapy was maintained and CVR was achieved. None of the patients in this study had to discontinue treatment due to TDF-associated adverse effects, and there was no significant elevation in serum creatinine levels during the treatment period. It was determined that two patients developed hepatocellular carcinoma during TDF treatment. Both patients were male, of advanced age, and treatment-experienced. Also, both had long-term CHB history and had developed HCC in the presence of cirrhosis.

\section{Discussion}

TDF monotherapy is efficient and safe in the long-term suppression of HBV $(5,6,12)$. In a study performed by Marcellin et al. (5) the CVR rate at the end of the 5th year of treatment in HBeAgpositive and negative patients was found to be $97 \%$ and $99 \%$, respectively. In a study by Buti et al. (6) the CVR rate at the end of the $7^{\text {th }}$ year of treatment in $\mathrm{HBeAg}$-positive and -negative patients was found to be $99.4 \%$ and $99.3 \%$, respectively. However, both of the studies reporting long-term results of TDF treatment were multi-center studies. Also, in these cases, emtricitabine could be added to TDF treatment for confirmed viremia at week 72 . In daily practice, we cannot add emtricitabine to TDF because of financial barriers. Therefore, our study is important to demonstrate real-life data for clinicians because of the high CVR rates achieved in both NA-naive and NA-experienced patients with TDF monotherapy.

Advantages of oral NA treatment compared to interferons are the more potent antiviral effect, good tolerance, lower side-effect profile, and good compliance (3). However, antiviral resistance

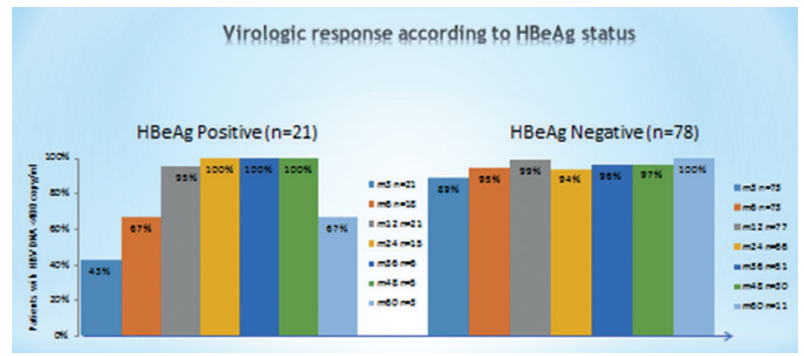

Figure 1. Virological response according to the hepatitis B envelope antigen status

HBeAg: Hepatitis B envelope antigen, HBV: Hepatitis B virus

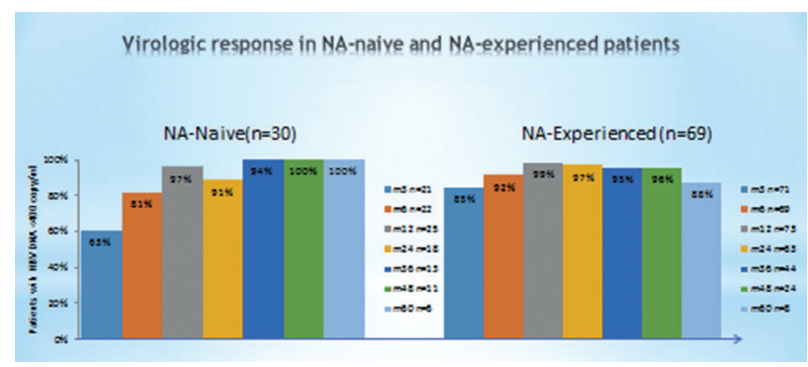

Figure 2. Virologic responses in nucleos(t)ide analogue-naive and nucleos(t)ide analogue-experienced patients

NA: Nucleos(t)ide analogue, HBV: Hepatitis B virus

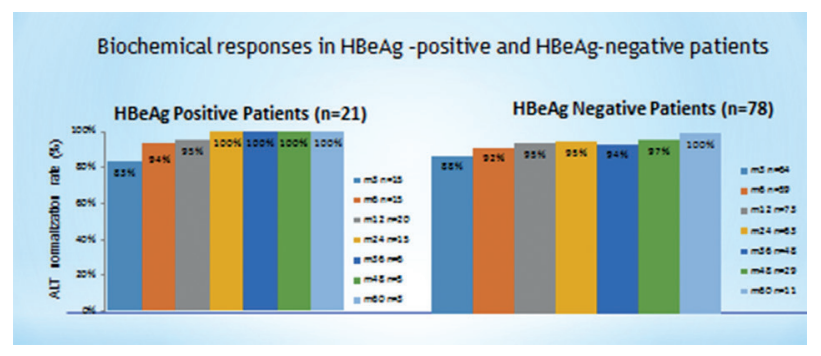

Figure 3. Biochemical responses in hepatitis B envelope antigen-positive and hepatitis $B$ envelope antigen-negative patients

HBeAg: Hepatitis B envelope antigen, ALT: Alanine aminotransferase

Biochemical responses in NA-naive and NA-experienced patients

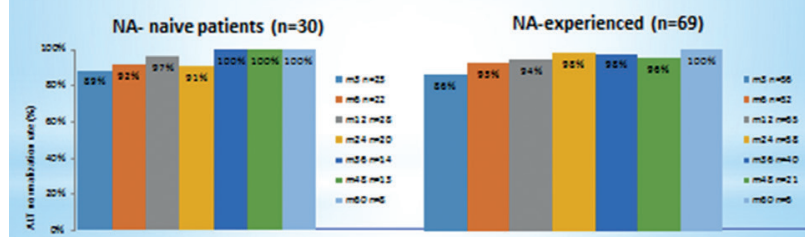

Figure 4. Biochemical responses in nucleos(t)ide analogue-naive and nucleos(t)ide analogue-experienced patients NA: Nucleos(t)ide analogue, ALT: Alanine aminotransferase 
that can be seen during NA treatment causes treatment failure. Currently, there are an increasing number of patients who used multiple NA treatments and experienced treatment failures (13). In our study, no statistically significant difference was found between CVR rates in NA-naive and NA-experienced patients at the 1st, $2^{\text {nd }}, 3^{\text {rd }}$, $4^{\text {th }}$, and $5^{\text {th }}$ years of the treatment. TDF monotherapy was found to be efficient in NA-experienced patients as it was in NA-naive patients $(8,9,10,11,14)$. However, data on long-term efficacy and safety in daily practice are still limited, especially in NA-experienced patients. When we evaluated the current studies of TDF treatment in NA-experienced patients, we observed that CVR rates over 4 years of therapy were given in only one study. Most of the other studies reported only short-term results. For this reason, we thought that our data reporting results over 5 years of TDF treatment in NA-experienced patients is important because it reports long-term results.

Multiple failures of NA therapies are a growing global problem. LAM is commonly used, especially in some parts of Asia, due to the high prevalence of CHB and its availability at a low cost (15). However, in the era when drugs with a high genetic barrier were not available, ADV and/or entecavir therapy was begun to manage LAM resistance (13). It has been determined that treatment response to TDF therapy was not affected in patients who were determined as having LAM resistance $(8,10,14,16,17,18,19)$. So far, TDF resistance has not been described in NA-experienced patients (20). In our study, drug resistance related to NA analogues previously used was not studied, but it was determined that being NA-experienced did not affect CVR rates ( $p \leq 0.05)$.

Virologic breakthrough developed in total of 7 patients during treatment. This resulted from poor drug compliance and the discontinuation of treatment on their own request in these patients. The drug had not been switched, TDF therapy was maintained regularly, and CVR was achieved. These results show us that poor drug compliance is an important factor in the development of virologic breakthrough. In accordance with our study, Jung et al. (14) reported that virologic breakthrough developed in a total of 5 patients due to poor medication compliance. The drug had not been switched, therapy was maintained regularly, and CVR was achieved in all of these patients.

In our study, virologic response rates achieved at $3^{\text {rd }}$ month and $6^{\text {th }}$ month were statistically significantly higher in the patients with advanced age, HBeAg-negative, lower baseline ALT values, and lower log HBV DNA values. In a study performed by Bakhshizadeh et al. (21) age, HBeAg positivity, higher baseline ALT values, and HBV DNA values were determined to be factors affecting CVR in univariate analyses, but $\mathrm{HBeAg}$ positivity and higher baseline HBV DNA levels were found to be independently associated with CVR in multivariate analyses.

\section{Study Limitations}

Our study design is retrospective and we could not evaluate drug resistance in our NA-experienced patients. Also, the number of patients who reached five years of treatment is quite low.

\section{Conclusion}

The long-term results of TDF monotherapy in both NA-naive and NA-experienced patients of our study comprising real-life data showed that TDF monotherapy was efficient and safe. Our long-term results with TDF therapy, especially in CHB patients who have developed multiple treatment failures to NA treatments that have caused problems in clinical practice, indicate that TDF therapy is a highly efficient and safe treatment option in this patient group.

\section{Ethics}

Ethics Committee Approval: The study were approved by Eskişehir Yunus Emre State Hospital of Local Ethics Committee, Informed Consent: Consent form was filled out by all participants.

Peer-review: Externally and Internally peer-reviewed.

\section{Authorship Contributions}

Surgical and Medical Practices: Pınar Korkmaz, Figen Çevik Çağlan, Nevil Aykın, Hasan Naz, Concept: Pınar Korkmaz, Figen Çevik Çağlan, Design: Pınar Korkmaz, Figen Çevik Çağlan, Data Collection or Processing: Pınar Korkmaz, Figen Çevik Çağlan, Nevil Aykın, Hasan Naz, Analysis or Interpretation: Pınar Korkmaz, Onur Toka, Literature Search: Pınar Korkmaz, Figen Çevik Çağlan, Writing: Pınar Korkmaz, Figen Çevik Çağlan.

Conflict of Interest: No conflict of interest was declared by the authors.

Financial Disclosure: The authors declared that this study received no financial support.

\section{References}

1. Heijtink RA, Kruining J de Wilde GA, Balzarani J de Clercq E, Schalm SW. Inhibitory effects of acyclic nucleoside phosphonates on human hepatitis $B$ virus and duck hepatitis $B$ virus infections in tissue culture. Antimicrob Agents Chemother. 1994;38:21802182.

2. Lam YF, Yuen MF, Seto WK, Lai CL. Current Antiviral Therapy of Chronic Hepatitis B: Efficacy and Safety. Curr Hepat Rep. 2011;10:235-243

3. European Association for the Study of the Liver. EASL clinical practice guidelines: management of chronic hepatitis B. J Hepatol. 2009:50:227-242

4. Lok AS, McMahon BJ. McMahon. Chronic Hepatitis B: Update 2009. Hepatology. 2009;50:661-662.

5. Marcellin P, Gane E, Buti M, Afdhal N, Sievert W Jacobson IM, Washington MK, Germanidis G, Flaherty JF, Aguilar Schall R, Bornstein JD, Kitrinos KM, Subramanian GM, McHutchison JG, Heathcote EJ. Regression of cirrhosis during treatment with tenofovir disoproxil fumarate for chronic hepatitis B: a 5-year open-label follow-up study. Lancet. 2013;381:468-475.

6. Buti M, Tsai N, Petersen J, Flisiak R, Gurel S, Krastev Z, Schall RA, Flaherty JF, Martins EB, Charuworn P, Kitrinos KM, Subramanian GM, Gane E, Marcellin P. Seven-year efficacy and safety of treatment with tenofovir disoproxil fumarate for chronic hepatitis B virus infection. Dig Dis Sci. 2015;60:1457-1464.

7. Patterson SJ, George J, Strasser SI, Lee AU, Sievert W, Nicoll AJ, Desmond PV, Roberts SK, Locarnini S, Bowden S, Angus PW. Tenofovir disoproxil fumarate rescue therapy following failure of both lamivudine and adefovir dipivoxil in chronic hepatitis B. Gut. 2011;60:247-254

8. van Bömmel F, de Man RA, Wedemeyer $H$, Deterding $K$, Petersen J, Buggisch P, Erhardt A, Hüppe D, Stein K, Trojan J, Sarrazin C, Böcher WO, Spengler U, Wasmuth HE, Reinders JG, Möller B, Rhode P, Feucht HH, Wiedenmann B, Berg T. Long-term efficacy of tenofovir monotherapy for hepatitis B virus-monoinfected patients after failure of nucleoside/nucleotide analogues. Hepatology. 2010;51:73-80. 
9. Keskin O, Ormeci AC, Baran B, Kabaçam G, Tüzün A, Karatayli E, Akyüz F, Karatayli S, Bozdayi AM, Onel D, Badur S, Idilman R, Kaymakoglu S, Yurdaydin C. Efficacy of tenofovir in adefovirexperienced patients compared with treatment-naive patients with chronic hepatitis B. Antivir Ther. 2014;19:543-550.

10. Baran B, Soyer OM, Ormeci AC, Gokturk S, Evirgen S, Bozbey HU, Akyuz F, Karaca C, Demir K, Besisik F, Onel D, Gulluoglu M, Badur S, Kaymakoglu S. Efficacy of tenofovir in patients with Lamivudine failure is not different from that in nucleoside/nucleotide analoguenaive patients with chronic hepatitis B. Antimicrob Agents Chemother. 2013;57:1790-1796.

11. Örmeci N, Özbaş B, Güner R, Özkan H, Yalçı A, Çoban Ş, Dökmeci A, Kalkan Ç, Akıncı H, Yüksel O, Başar Ö, Yüksel I, Balık l. Tenofovir-best hope for treatment of chronic hepatitis B infection? Turk J Gastroenterol. 2015;26:322-327.

12. Kitrinos KM, Corsa A, Liu Y, Flaherty J, Snow-Lampart A, Marcellin P, Borroto-Esoda K, Miller MD. No detectable resistance to tenofovir disoproxil fumarate after 6 years of therapy in patients with chronic hepatitis B. Hepatology. 2014;59:434-442.

13. Kim YJ, Sinn DH, Gwak GY, Choi MS, Koh KC, Paik SW, Yoo $B C$, Lee JH. Tenofovir rescue therapy for chronic hepatitis B patients after multiple treatment failures. World J Gastroenterol. 2012;18:6996-7002.

14. Jung SK, Kim KA, Ha SY, Lee HK, Lee HK, Kim YD, Lee BH, Paik WH, Kim JW, Bae WK, Kim NH, Lee SJ, Jwa YJ. Tenofovir disoproxil fumarate monotherapy for nucleos(t)ide analogue- naive and nucleos(t)ide analogue-experienced chronic hepatitis $B$ patients. Clin Mol Hepatol. 2015;21:41-48.

15. European Association for the Study of the Liver. EASL clinical practice guidelines: management of chronic hepatitis B. J Hepatol. 2012;57:167-185.

16. Zoulim F. Hepatitis B virus resistance to antiviral drugs:where we are going? Liver Int. 2011:11:111-116.

17. Kuo A, Dienstag JL, Chung RT. Tenofovir disoproxil fumarate for the treatment of lamivudine-resistant hepatitis B. Clin Gastroenterol Hepatol. 2004;2:266-272.

18. Lo AO, Wong VW, Wong GL, Tse YK, Chan HY, Chan HL. Efficacy of tenofovir switch therapy for nucleos(t)ide-experienced patients with chronic hepatitis B. Aliment Pharmacol Ther. 2015;41:11901199.

19. Kim HJ, Cho JY, Kim YJ, Gwak GY, Paik YH, Choi SM, Koh CK, Paik SW, Yoo BC, Lee JH. Long-term efficacy of tenofovir disoproxil fumarate therapy after multiple nucleos(t)ide analogue failure in chronic hepatitis B patients. Korean J Intern Med. 2015;30:32-41.

20. Lada O, Benhamou Y, Cahour A, Katlama C, Poynard T, Thibault V. In vitro susceptibility of lamivudine-resistant hepatitis B virus to adefovir and tenofovir. Antivir Ther. 2004;9:353-363.

21. Bakhshizadeh F, Hekmat S, Keshvari M, Alavian SM, Mostafavi E, Keivani H, Doosti-Irani A, Motevalli F, Behnava B. Efficacy of tenofovir disoproxil fumarate therapy in nucleoside-analogue naive Iranian patients treated for chronic hepatitis B. Hepat Mon. $2015 ; 15: 25749$ 